\title{
Developing Analysis Models for Implementing Construction Enterprise Resource Planning System
}

\author{
Meng-Hsueh LEE ${ }^{\mathrm{a}}$, H. Ping TSERNG ${ }^{\mathrm{b}}$ \\ a Ph.D. Student, Department of Civil Engineering, National Taiwan Univ., Taipei, Taiwan. \\ D92521016@ntu.edu.tw \\ b Associate Professor, Department of Civil Engineering, National Taiwan Univ., Taipei, Taiwan. \\ hptserng@ce.ntu.edu.tw
}

\begin{abstract}
To face the worldwide competition and pervasively use of new information technologies, enterprise resource planning (ERP) systems are executed and implemented to enhance their competition capabilities. In order to implementing ERP systems successfully in construction industries, an appropriate analysis model ICE-PP (IDEF0 in Construction Engineering with The Proven Path) is presented in the paper and executed in the real case for the implement of construction ERP system. The ICE-PP including sixteen processes used as a reference model for the construction enterprise to implement the ERP system. The paper mainly describes the real case that experience in Taiwan construction enterprise and explain the critical steps are needed for the important procedures to successfully implement the ERP system. Also, with the reference model, the implementing process could be improved effectively and reduce the probability of failing implementing ERP system.
\end{abstract}

Keywords: Enterprise Resource Planning; Construction Industry; Analysis Models

\section{Intriduction}

There are only a few construction factory cases that induct ERP. Besides, only the enterprises involved in the induct process know the key point. That is the reason why we lack of the important reference cases about construction factory induct ERP. Therefore, if we could establish the analysis model about construction factory induct ERP through literature review, experts interview and participate in one of them, the extra induct cost and chances of failure induction will reduce. In order to implementing ERP systems successfully in construction industries, an appropriate analysis model ICE-PP (IDEF0 in Construction Engineering with The Proven Path) is presented in the paper and executed in the real case for the implement of construction ERP system.[2][4]

\section{The limit and Methodology of the Research}

\subsection{The limit of the Research}

(1) Due to there are few factories implemented the ERP system in the construction industry, it is impossible to collect amounts of research samples such as that in the manufacturing, electronics and information industry. Therefore, the research only focuses on few representative firms.[2][3]

(2) Construction firms successfully implemented the ERP system had not exceeded one year, and still been pending in system adapting and transition stage. For the difficulty of analyzing their history information, financing and accounting forms, the research only can apply expert interviewing method to explore all kinds of problems and solutions involved in the implementing process.

(3) Although construction factories are core characters in the construction industry, the industrial behavior still includes architecture investment and contract work system. The scope of the research can be more extensive if studying in different characters within the construction life cycle. Though, for the restriction of the research, it focuses on proprietors, construction factories and professional contractors without the consulting firms and the architect offices.

(4) For the construction firm "company A" successfully implemented the ERP system, the research only can apply expert interviewing method and literature reviewing to comprehend the implementing condition.

(5) The construction firm "company B" had not entirely implemented the ERP system yet, the research only focuses on stages of plan to implement and partially implement progress for both companies, and applies literature reviewing, expert interviewing and practically participating.

\subsection{The Function Analysis of IDEF0}


This publication announces the adoption of the Integration Definition Function Modeling (IDEF0) as a Federal Information Processing Standard (FIPS). This standard is based on the Air Force Wright Aeronautical Laboratories Integrated ComputerAided Manufacturing (ICAM) Architecture, Part II, Volume IV - Function Modeling Manual (IDEF0),June 1981.

This standard describes the IDEF0 modeling language (semantics and syntax), and associated rules and techniques, for developing structured graphical representations of a system or enterprise. Use of this standard permits the construction of models comprising system functions (activities, actions, processes, operations), functional relationships, and data (information or objects) that support systems integration.

This standard is the reference authority for use by system or enterprise modelers required to utilize the IDEF0 modeling technique, by implementors in developing tools for implementing this technique, and by other computer professionals in understanding the precise syntactic and semantic rules of the standard [5].

\subsection{The Proven Path Implement Processes Method}

The Proven Path brought out by Oliver Wight Company in 1990, focused on 16 implementing processes and detailedly analyzed steps and points for attention in every processes of implement MRPII, was regarded as an important reference of MRPII.[1]

(1) Audit/Assessment I : An analysis of the company's current situation, problems, opprtunities, strategies, etc. This analysis will serve as the basis for putting together a short-term action plan to bridge the time period until the detailed project schedule is develop.

(2) First-Cut Education: A group of executives and operating managers from with the company must learn, in general terms, how MRPII works; what it consists of; how it operates; and what is required to implement and use it properly.

(3) Vision Statement : A written document defining the desired operational environment to be achieved with the implementation of MRPII.

(4) Cost/Benefit: A process to generate a written document that spells out the costs of implementation and the benefits of operation MRPII successfully, and result in a formal decision whether or not to process with MRPII.
(5) Project Organization : Creation of an Executive Steering Committee; an operational-level project team, consisting mainly of the managers of operating departments throughout the company; and the selection of the full-time project leader and other people who will work full time on the project.

(6) Performance Goals : Agreement as to whtch performance categories are expected to improve and what specific levels they are expected to reach.

(7) Initial Education : Ideally 100 Percent, a minimum of 80 percent, of all of the people in the company need to receive some education on MRPII as part of the implementation process. People need to know what, why, and how these changes will affect them.

(8) Sales, Logistics, and Manufacturing Processes : A detailed statement of how the sales/marketing, logistics and manufacturing functions will operate following the implementation of MRPII, backed up by a detailed project plan necessary to achieve this.

(9) Planning and control Processes : Development and implementation of policies and processes necessary for effective planning and execution, from sales \& operations planning down through the detailed schedules for the plants and suppliers.

(10) Data management: MRPII, to be successful, requires levels of data integrity far higher than most companies have ever achieved. Inventory recoeds, bills of material, routings, and other data need to become highly accurate, complete and properly structured.

(11) Process Improvement : Improvement in physical processes are the heart of a Just-in-Time implementation, and can play a significant role in Quick-Slice MRP. It's optional in an MRPII company-wide implementation, ofter not a major step. However, opportunities for improving physical processes should not be overlook-before, during, and after-MRPII implementation.

(12) Software : Acauisition, installation, and maintenance of the necessary softweare to sipport all MRPII functions.

(13) Pilot and Cutover: Beginning to operate the business with the new set of tools-on a very contrilled and closely managemd basis.

(14) Performance Measurements : Beginning to track actual results and compare them to the performance goals defined in step6.

(15) Audit/Assessment II : A focused evaluation of the company's situation, problems, 
opportunities, and strategies following the implementation. It is the driver via which the company moves into its next improvement initiative.

(16) Ongoing Education : Initial education for new people coming into the company and refresher education for continuing employees.

\subsection{The Amendment of The Proven Path}

Though assume the principle of The Proven Path endures from MRPII to ERP, the application of the system software has been developed from manufacture resource to integrating all resource demand of the business. For this factor, it requires proper amendments. The main amendments are as followed: The (8) stage is "Sale, Logistics and Manufacture Processes". For the enterprise resource planning includes five managements scopes such as manufacture, marketing, human resource, research, and finance, thus revises "Sale, Logistics and Manufacture Processes" to "Business Operation Processes".

\subsection{The coding method of the ICE-PP (IDEF0 in Construction Engineering of the Proven Path )}

The coding method follows the coding principle of the IDEF0: first layer is A0 "Construction Firm ERP Project", second layer are A1 "ERP Pre-implement Preparation" and A2 "ERP Implement Operations", third layer are A11 "Audit/Assessment I", A12 "First-Cut Education", A13 "Vision Statement", A14 "Cost/Benefit", A15 "Project Organization", and A16 "Performance Goals", as shown in Figure 1.

\section{Cases Study}

The first case A, general contractor, established since 1984, contracts for general construction and build includes residences, hillside villas, office buildings, technology factories, school, hospital, and bundled or packed goods mart, etc. This firm adopts SAP System.

The case B was established since 1976. This enterprise had traditional Chinese operate characteristic, with American and Japan business culture and modern management philosophy. This enterprise was choiced People Soft System.

\section{Comprehensive Discussions and the Analysis Model Revision}

\subsection{Discussions of Audit/Assessment}

The main idea of classifying A11 "Audit/Assessment I", A221 "Performance Measurements" and A222 "Audit/Assessment II" in to the "Discussions of
Audit/Assessment" is to evaluate the present operation performances and future needs. Take A11 "Audit/Assessment I" for instance, the purpose is to determine the business present condition and bring out requirements of improvement and suggestion schemes. A221 "Performance Measurements" is to calculate the beneficial result of implement, and bring out the future possible improvement schemes in A222 "Audit/Assessment II".

The stage of Audit/Assessment is the starting point of the project implement. If the company's core objective is not defined certainly in this stage, it will lead to the result as "A small discrepancy leads to a great error." Thus the Audit/Assessment is the key point of the implement.

According to the interviews, company B concerned to integrate construction management resource into the ERP system, while company A acquired to accomplish business operation and management. The reason that company A differs from other cases is which has already developed the construction management related application system before implementing ERP, and the system accomplished the construction management industry demand. As to the ERP system, accomplished enterprise resource planning of all subsidiary companies of company A. For different considerations, it results in different consequences in planning relative modules of the system. The research studies on cases and concludes several audit/assessment analysis scopes as follows:

The first is the demand scope, divided as internal and external demands. Internal demands include high-level supervisors' and every divisions' demands toward the system. For the work and finance division are the core in the construction industry, both divisions and high-level supervisors' demands are supports for ERP project. External demands derive from all characters upstream to downstream in the industry, such as proprietors, construction factories and professional contractors, the enterprise tries to accomplish every different external demands to catalyze ERP project.

The second is the integration scope, includes cross processes, cross divisions, cross projects and cross undertakings integration. The cross processes integrations, implies as small as the construction sites coordination to as large as the material factories and manufacture factories coordination. The cross divisions integration, coordinates the construction project division and financial accounting division, as the most complicated example in the construction industry. The cross projects integration implies the resource modulation and distribution within projects. The cross undertakings integration implies plan, design and materials supply coordination, or 
construction and mechanical and electrical assembling projects coordination.

The third is time scope, approximately sorts out as short-term, medium term and long-term stages. The short-term stage includes business demand and resource modulation. The medium term stage implies integrating all internal resource in business, and improving the business competency. The long-term stage plans for supply chain integration, cross regional organizations coordinative design integrations, and etc.

From another point of view, the integration scope implies the character of demander, but as if to integrate the processes in construction sites, implies the executors' demand. As to integrate the resource within divisions and projects or even cross undertakings, it implies demand of operation and management or strategy development scope.

\subsection{Discussions of Education/Training}

The research concludes A12 "Initial Education", A211 "First time Education" and A223 "Continued Education" to the "discussions of education/training", and the relative topics are as follows:

Before the selection, or after the selection but before implement the ERP system, it is necessary to train the ERP group for concepts, rear-end management of the system and implement methodology, to make the group members acquaint to the ERP system as large as an aircraft carrier, and make them more familiar with the system implement to implement the ERP project favorably.

Refers to company A with SAP system, and the two bid soliciting teams, the main principle of the education/training is to train seed members by consultants, then designed the user's guidebook and trained general users by seed members.

The research discovers that case companies both have common characteristic, which is to train internal employees constantly to keep enterprise progressing and maintain as a market forerunner. Wherein the enterprise with larger training budgets authorizes management consulting company to train, and that with fewer budgets attends the educations hold by the government or academic circle.

From case study and expert interview concludes that the education/training in the implement progress is the key factor for practically execution in the future. If it is possible to train general users as seed members, the system is able to bring the largest beneficial result. However, the biggest problems are the system acquaintance of general users and the concept recognition of operation processes among divisions. Thus by constant training, conquers the obstacles of practically implementing the system.

\subsection{Discussions of Visions and Goals}

The research concludes A13 "Vision Statement" and A16 "Performance Goals" to the "Discussions of Visions and Goals". Visions are abstract description, while performance goals topics are more specific, but both are objectives traced by every divisions and stratums no matter neither abstract nor specific.

The enterprise visions in the studied cases, company B planed to integrate the resource among construction related undertakings in short-term, and to integrate the whole resource within the company group in longterm. Company $\mathrm{C}$ planed to eliminate the old system and improve enterprise competency in short-term, and to expand domestic and foreign engineering construction markets in long-term. Every factor of vision statements and performance goals derives from internal audit/assessment. If it is possible to point out the enterprise demands, and plan for short-term, medium term and long-term strategies, visions and goals induced by demands will be obvious, and will provide bid tending factories more certain develop policy to bring out solutions much specifically.

\subsection{Discussions of Cost/Benefit Analysis}

Cost constitutes of the human resource cost, the administration cost, the consulting service cost, the training cost, the system cost and etc. The human resource cost includes planning team and implementing team. The administration cost implies all conferences cost within the progress. The consulting service and training cost divides in internal and external parts. The system cost contains expense of software and hardware.

According to the analysis of consultant service data of company A in the research, the manpower time require for the project module is higher than any other application module. Obviously, the importance of the project management in the construction industry is not substitutable for other modules.

\subsection{Discussions of Project Organization}

According to the project organization of the studied cases, the larger scale of the enterprise, the higher cost of human resource. In every division, even the human resource distribution of the ERP system module, at least one seed member of specific duty is required. Seed members simply with information background are also appreciated. On account of members with information background not only can make effort to information techniques within implement progress, but also perform assistant roles for the unacquaintance to information techniques, and which can improve team cooperation and beneficial results of implementing. Moreover, as the maintenance point of view, information members 
should transfer the techniques from consultant service into enterprise internal, thus can handle on its own when requiring for maintenance in the future, and can code reporting program on its own when requiring for list reporting, without help by hiring consultants.

\subsection{Discussions of Planning and Control Management}

The main idea of planning and control processes is the project management of the implement process. The research based on cases study concludes several management points such as schedule management, cost management, document management, communication management, contract management, risk management and etc. Wherein the cost management is mentioned above in the Discussions of Cost/Benefit Analysis, so this section describes progress, document, communication and contract management.

The principle of schedule management: After permission of high-level supervisors, project members establish the implement time arrangement together with consultants. Every activity should follow the time arrangement. If encountering sudden events or progress delay, it must response to the high-level committee to make proper revision toward the plan schedule.

The principle of document management: In the entire progress from the first implement conference to fully implement, every relative documents should be categorized systematically, such as conference records, conference briefings, references, implement documents, training materials, and etc. It will be much easier to acquire and absorb information in documents in the future if which can be categorized more systematically. Besides, documents should backup periodically and even in other place, to prevent from irresistible accidents and reduce the risk of implement failure.

The principle of communication management: the communication management is for internal and external. The internal objects are company project members, and the external object is the implement consulting company. The internal communication requires high-level supervisors endow sufficient right, responsibility and obligation to diminish the coordination and integration of internal organization, and avoid unnecessary disputes. The external communication requires curtailing the acquaintance divergence between the implementing company and the implement consult, and maintains intimate communication. If it is lack of freely communication between the both, the acquaintance divergence of project demands will increase the risk of implement failure.
The principle of contract management: The contract management of implement ERP system is the key point of protecting both sides rights and obligations. In addition to the check and accept payment mechanism, the maintenance of operation of ERP system is the main part in the contract.

\subsection{Discussion of Information Technology Topic}

The topic of information technology was combined A214 "Data Manage" and A216 "Soft". This topic not only includes each enterprise's original imformation system such as schedule management system, drawing and design system, document management system, engineering management system, bus also includes the modules of ERP system, for instance materiel management, pocurement management, cost control, contract management, funding management, knowledge managemtn, quality management, facility and maintenance management, asset management, finance and ccounting management, sales management, production management, EIP, marketing analysis system , bidding preparation management, and human resource management ect.

To collect the orginal system for general contractor, it would be easily understand the main system was focus on construction engineering management (planning and design, cost estimation, and scheduling).

The research listed all of modules from this case study, and classified the characteristic of construction management, business management, and cross industry. The Table2 was statistics five modules of construction management, six modules of cross industry, and ten modules of business management.

\section{Conclusion}

The characteristic of this research is the systematic analysis model that established by logical way. The study based on the real cases of Taiwan implements ERP. Future study could modify the model in different angle, such as owner, architect, consultant etc., this will strengthen this model's generality and substantially reduce and properly control the uncertain factors when construction factories induct ERP.

\section{Reference}

[1] Wallace, T. F.,'MRPII Making It Happen”, TheOliver Wight Companies, 1990.

[2] Shi, J. J.,'Enterprise Resource Planning for Construction Business Management", Journal of Construction Engineering and Management", ASCE, March/April2003, pp.214-221. 
[3] Hans V.,"Enterprise Resource Planning in a large construction firm: implementation analysis." Construction Management and Economics,Vol.21, July 2003, pp.511-521.

[4] Wei C. C.,"A comprehensive framework for selecting an ERP system", International Journal

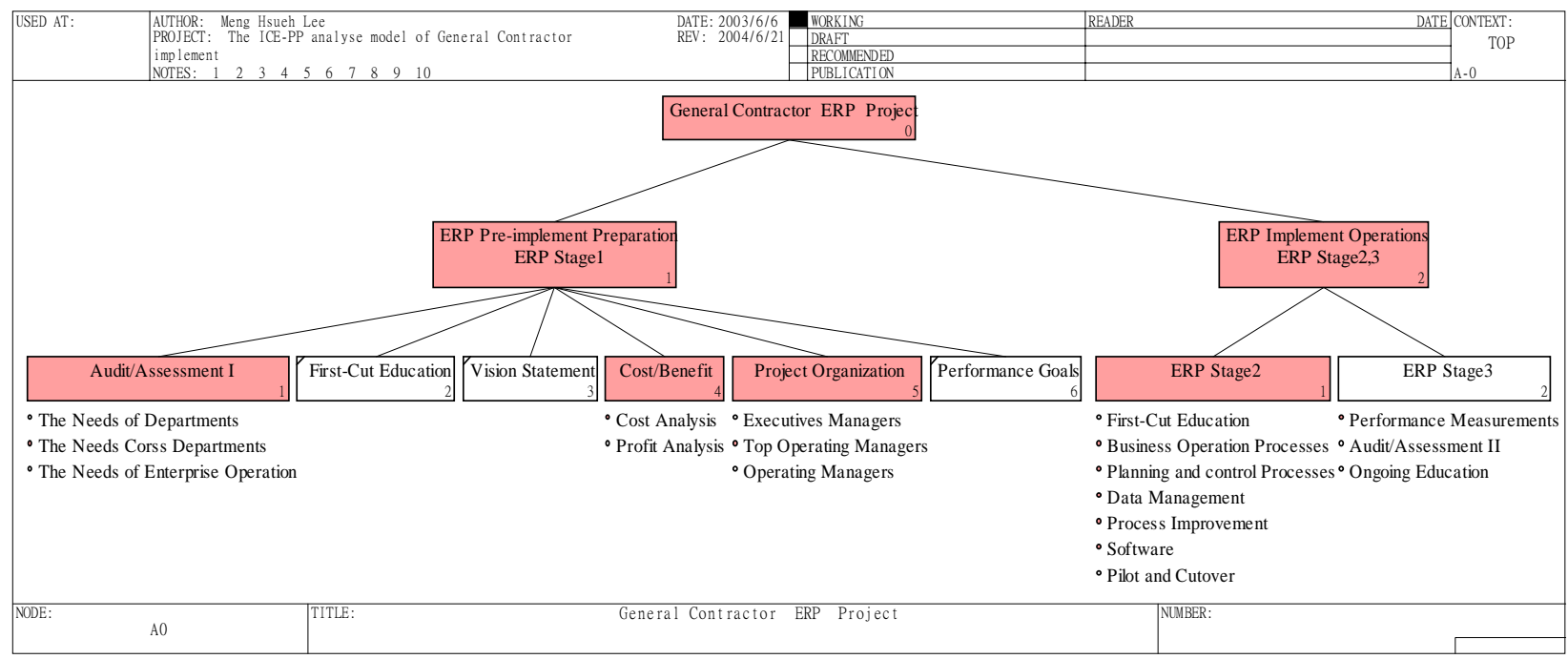

Figure 1. The Diagram of ICE-PP analysis model

Table 2. Comparing ERP modules from case studies

\begin{tabular}{|c|c|c|c|c|}
\hline \multicolumn{2}{|c|}{$\begin{array}{l}\text { ERP System } \\
\text { Module Name }\end{array}$} & \multirow{2}{*}{$\mathrm{A}$} & \multirow[t]{2}{*}{ B } & \multirow{2}{*}{$\begin{array}{l}\text { Industry Category } \\
\text { Cross Industry }\end{array}$} \\
\hline 1 & $\begin{array}{l}\text { Materiel } \\
\text { Management }\end{array}$ & & & \\
\hline 2 & $\begin{array}{l}\text { Pocurement } \\
\text { Management }\end{array}$ & & $\mathrm{O}$ & Cross Industry \\
\hline 3 & Cost Control & $\mathrm{O}$ & $\mathrm{O}$ & $\begin{array}{l}\text { Business } \\
\text { Management }\end{array}$ \\
\hline 4 & $\begin{array}{l}\text { Engineering } \\
\text { Management }\end{array}$ & & & $\begin{array}{l}\text { Construction } \\
\text { Management }\end{array}$ \\
\hline 5 & $\begin{array}{l}\text { Contract } \\
\text { Management }\end{array}$ & & & $\begin{array}{l}\text { Construction } \\
\text { Management }\end{array}$ \\
\hline 6 & $\begin{array}{l}\text { Engineering Planing } \\
\text { and Schedule } \\
\text { Management }\end{array}$ & $\mathrm{O}$ & $\mathrm{O}$ & $\begin{array}{l}\text { Construction } \\
\text { Management }\end{array}$ \\
\hline 7 & Fund Management & $\mathrm{O}$ & $\mathrm{O}$ & $\begin{array}{l}\text { Business } \\
\text { Management }\end{array}$ \\
\hline 8 & $\begin{array}{l}\text { Knowledge } \\
\text { Managemtn }\end{array}$ & & $\mathrm{O}$ & $\begin{array}{l}\text { Business } \\
\text { Management }\end{array}$ \\
\hline 9 & $\begin{array}{l}\text { Quality } \\
\text { Management }\end{array}$ & $\mathrm{O}$ & & Cross Industry \\
\hline 10 & $\begin{array}{ll}\text { Facility and } \\
\text { Maintenance } \\
\text { Management }\end{array}$ & $\mathrm{O}$ & & Cross Industry \\
\hline 11 & Asset Management & $\mathrm{O}$ & $\mathrm{O}$ & $\begin{array}{l}\text { Business } \\
\text { Management }\end{array}$ \\
\hline
\end{tabular}

\begin{tabular}{|c|c|c|c|c|}
\hline \multicolumn{2}{|c|}{$\begin{array}{l}\text { ERP System } \\
\text { Module Name }\end{array}$} & A & B & Industry Category \\
\hline 12 & $\begin{array}{l}\text { Finance and } \\
\text { Accounting } \\
\text { Management }\end{array}$ & $\mathrm{O}$ & $\mathrm{O}$ & $\begin{array}{l}\text { Business } \\
\text { Management }\end{array}$ \\
\hline 13 & Sales Management & $\mathrm{O}$ & & Cross Industry \\
\hline 14 & $\begin{array}{l}\text { Document } \\
\text { Management } \\
\text { System } \\
\end{array}$ & $\mathrm{O}$ & $\mathrm{O}$ & $\begin{array}{l}\text { Business } \\
\text { Management }\end{array}$ \\
\hline 15 & $\begin{array}{l}\text { Production } \\
\text { Management }\end{array}$ & $\mathrm{O}$ & & Cross Industry \\
\hline 16 & EIP & & $\mathrm{O}$ & $\begin{array}{l}\text { Business } \\
\text { Management }\end{array}$ \\
\hline 17 & $\begin{array}{l}\text { Marketing Analysis } \\
\text { System }\end{array}$ & & $\mathrm{O}$ & $\begin{array}{l}\text { Construction } \\
\text { Management }\end{array}$ \\
\hline 18 & $\begin{array}{l}\text { Bidding Preparation } \\
\text { Management }\end{array}$ & & $\mathrm{O}$ & $\begin{array}{l}\text { Construction } \\
\text { Management }\end{array}$ \\
\hline 19 & $\begin{array}{l}\text { Capital } \\
\text { Management }\end{array}$ & & $\Omega$ & $\begin{array}{l}\text { Business } \\
\text { Management }\end{array}$ \\
\hline 20 & $\begin{array}{l}\text { Account } \\
\text { Management }\end{array}$ & $\mathrm{O}$ & $\mathrm{O}$ & $\begin{array}{l}\text { Business } \\
\text { Management }\end{array}$ \\
\hline 21 & $\begin{array}{l}\text { Human Resource } \\
\text { Management }\end{array}$ & & $\mathrm{O}$ & $\begin{array}{l}\text { Business } \\
\text { Management }\end{array}$ \\
\hline
\end{tabular}

of Project Management, Vol.22, 2004, pp.161-169.

[5] Integration definition for function modeling ( IDEF0 ).Draft federal information processing standards publication 183 .

http : //www.idef.com ( 1993 ) 